\title{
PERILAKU MAKAN DAN STATUS GIZI ANAK USIA SEKOLAH DASAR DI SD CIKANCUNG 04 DESA MANDALASARI KABUPATEN BANDUNG
}

\author{
Maya Indriati \\ Dosen Program Studi Diploma Tiga Kebidanan STIKes Dharma Husada Bandung
}

\begin{abstract}
ABSTRAK
Perilaku makan merupakan kebiasaan makan yang bisa diubah. Perilaku makan yang baik perlu dibentuk sebagai upaya untuk memenuhi kebutuhan gizi. Perilaku makan yang tidak sesuai akan menyebabkan asupan gizi berlebih atau sebaliknya kekurangan. Asupan berlebih menyebabkan kelebihan zat gizi, sebaliknya asupan makanan yang kurang akan menyebabkan tubuh menjadi kurus dan rentan terhadap penyakit. Tujuan penelitian adalah untuk menganalisis hubungan perilaku makan dan status gizi pada anak usia sekolah dasar di SD Cikancung 04 Desa Mandalasari. Penelitian ini merupakan penelitian korelasi dengan teknik pengambilan data total sampling. Sampel penelitian berjumlah 170 orang meliputi anak kelas 1 sampai dengan anak kelas 6, pengumpulan data untuk mengukur perilaku makan dilakukan dengan menggunakan kuesioner baku Child Eating Behaviour Questionnaire (CEBQ) sedangkan untuk status gizi dilakukan dengan mengukur TB dan BB anak. Hasil penelitian menunjukkan bahwa terdapat hubungan antara perilaku makan dan status gizi pada anak usia sekolah dasar di SD Cikancung ( $p$ value 0,001 ).
\end{abstract}

\section{Kata kunci : Perilaku makan, status gizi.}

\section{Pendahuluan}

Masalah gizi pada hakikatnya adalah masalah kesehatan masyarakat, namun penanggulangannya tidak dapat dilakukan dengan pendekatan medis dan pelayanan kesehatan saja. Salah satu indikator yang menggambarkan tingkat kesejahteraan masyarakat suatu negara adalah status gizi anak. Kekurangan gizi pada anak dapat disebabkan oleh aspekaspek yang multifaktor, oleh karena itu penanggulangannya harus melibatkan sektor terkait. Kesehatan dan gizi merupakan faktor yang penting, karena secara langsung berpengaruh terhadap kualitas sumber daya manusia sehingga diperlukan upaya peningkatan status gizi masyarakat melalui perbaikan gizi, baik dalam lingkungan keluarga maupun gizi individu. ${ }^{1}$

Walupun berdasarkan hasil Survei Demografi dan Kesehatan Indonesia (SDKI) 2017, angka kematian bayi/anak menunjukkan angka yang lebih rendah yaitu menurun dari 40 per 1000 kelahiran di tahun 2012 menjadi 32 per 1000 kelahiran di 2017. Begitu pula dengan Hasil Riset Kesehatan (RISKESDAS) 
tahun 2018 yang menunjukkan proporsi status gizi kurus dan sangat kurus pada anak adalah sebesar $10,2 \%$ turun dari tahun 2013 yaitu sebesar 12,1\% serta proporsi status gizi gemuk yang juga mengalami penurunan dari 11,9\% pada tahun 2013 menjadi $8,0 \%$ pada tahun 2018. Akan tetapi prevalensi anak-anak dengan kelebihan berat badan dan obesitas telah meningkat di seluruh dunia selama beberapa dekade terakhir. Hal ini menyebabkan peningkatan prevalensi global dari 4,2\% pada tahun 1990 menjadi $6,7 \%$ pada tahun 2010, dan prevalensinya diperkirakan mencapai $9,1 \%$ pada 2020 Selain itu, di sebagian besar dunia pula selama 30 tahun terakhir berjuta-juta anak meninggal karena malnutrisi, hampir 16 juta anak meninggal karena kelaparan. ${ }^{2,3}$

Status gizi kurang merupakan kondisi tidak sehat yang ditimbulkan karena tidak tercukupinya kebutuhan makanan yang diperlukan oleh tubuh. Pada keadaan gizi kurang akan mengakibatkan terhambatnya proses tumbuh kembang anak. Sedangkan status gizi lebih akan menyebabkan obesitas pada anak dan akan berisiko menderita penyakit degeneratif. Oleh karena itu, masalah tentang status gizi perlu diatasi bagi yang sudah terkena dan perlu dicegah untuk yang belum terkena masalah status gizi agar masalah gizi di Indonesia dapat berkurang. ${ }^{1}$

Program perbaikan gizi masyarakat secara umum ditunjukan untuk meningkatkan kemampuan, kesadaran dan keinginan masyarakat dalam mewujudkan kesehatan yang optimal khususnya pada bidang gizi, terutama bagi masyarakat berpenghasilan rendah baik desa maupun kota. Kegiatan pokok Kementrian Kesehatan dalam mengimplementasikan perbaikan gizi masyarakat meliputi: peningkatan pendidikan gizi, penanggulangan kurang energi protein (KEP), anemia gizi besi, gangguan akibat kurang yodium (GAKY), kurang vitamin A, dan kekurangan zat gizi. Adapun sasaran pokok program perbaikan gizi masyarakat yakni menurunnya prevalensi gizi kurang pada balita, terlaksananya penanggulangan kurang energi protein (KEP) anemia gizi besi, gangguan akibat kurang yodium (GAKY) dan kurang vitamin. ${ }^{3}$

Perilaku makan pada anak juga berperan penting terhadap status gizinya. Perilaku makan merupakan kebiasaan makan yang bisa diubah dan diduga merupakan prediktor yang kuat bagi terjadinya obesitas. Perilaku makan juga merupakan tingkah laku manusia atau kelompok manusia dalam memenuhi kebutuhan makan. Umumnya, perilaku makan anak sekolah masih dipengaruhi Jurnal Penelitian Kesehatan STIKes Dharma Husada Bandung 
oleh kelompok ataupun orangtuanya dan sekolah dapat membentuk perilaku makan anak, karena di lingkungan sekolah anak mudah terpapar jajanan kaki lima dan anak mempunyai kemampuan membeli disebabkan harganya murah, menarik, dan bervariasi. $^{4}$

Perilaku makan yang baik perlu dibentuk sebagai upaya untuk memenuhi kebutuhan gizi. Perilaku makan yang tidak sesuai akan menyebabkan asupan gizi berlebih atau sebaliknya kekurangan. Asupan berlebih menyebabkan kelebihan zat gizi. Sebaliknya, asupan makanan yang kurang dari yang dibutuhkan akan menyebabkan tubuh menjadi kurus dan rentan terhadap penyakit. Perilaku makan yang baik juga perlu dikembangkan untuk menghindari interaksi negatif dari zat gizi yang masuk dalam tubuh. ${ }^{5}$

Menurut survei awal yang dilakukan oleh peneliti di pada 10 ibu/orang tua di Desa Mandalasari Kabupaten Bandung diperoleh hasil bahwa 5 ibu mengatakan memberikan makanan yang sama pada anak dalam satu hari, $2 \mathrm{ibu}$ mengatakan memberikan makanan yang anak sukai saja, 2 ibu mengatakan memberikan makanan yang berbeda setiap makan, dan 1 ibu mengatakan memberikan makanan teratur dan jenis makanan yang sehat (tidak siap saji), kemudian dari 10 anak yang diukur BB dan TB nya, diketahui bahwa 3 anak memiliki BB dan TB sesuai umur, 5 anak memiliki BB berlebih, 2 anak memiliki BB yang kurus/tidak sesuai dengan umur.

Berdasarkan uraian diatas peneliti tertarik untuk melakukan penelitian tentang Perilaku Makan dan Status Gizi Anak Usia Sekolah Dasar di SD Cikancung 04 Desa Mandalasari Kabupaten Bandung.

\section{Metode Penelitian}

Jenis penelitian yang digunakan adalah penelitian korelasi. Sampel dalam penelitian ini adalah seluruh anak usia sekolah dasar di SD Cikancung 04 Desa Mandalasari Kecamatan Cikancung yang dipilih secara total sampling dan memenuhi kriteria inklusi dan eksklusi. Adapun kriteria tersebut adalah 1) Anak usia sekolah kelas 1-6, 2) Anak yang diasuh dan tinggal satu rumah dengan orang tua, 3) Anak dalam keadaan sehat. Sedangkan kriteria eksklusinya adalah; 1) Anak sedang menjalani pengobatan atau sedang sakit, 2) Anak tidak hadir pada saat dilakukan penelitian.

Pengumpulan data untuk mengukur perilaku makan dilakukan dengan menggunakan kuesioner baku Child Eating Behaviour Questionnaire (CEBQ) sedangkan untuk status gizi dilakukan dengan mengukur TB dan BB anak. 
Hasil dan Pembahasan

Tabel 1: Distribusi Karakteristik Sekolah Dasar

\begin{tabular}{lcc}
\hline \multicolumn{1}{c}{ Karakteristik } & f & \% \\
\hline Umur & & \\
7-8 tahun & 28 & 16,47 \\
$>8-9$ tahun & 29 & 17,05 \\
$>$ 9-10 tahun & 26 & 15,30 \\
$>10-11$ tahun & 30 & 17,65 \\
$>11-12$ tahun & 30 & 17,65 \\
$>12-13$ tahun & 27 & 15,88 \\
\hline Jenis Kelamin & & \\
Laki-Laki & 84 & 49,42 \\
Perempuan & 86 & 50,58 \\
\hline \multicolumn{1}{c}{ Total } & $\mathbf{1 7 0}$ & $\mathbf{1 0 0}$ \\
\hline
\end{tabular}

Berdasarkan Tabel 1, didapatkan hasil bahwa karakteristik anak usia sekolah dasar berdasarkan umur hampir merata. Responden dengan umur 7-8 tahun sebanyak 28 orang $(16,47 \%)$, umur $>8-9$ tahun sebanyak 29 orang $(17,05 \%)$, umur $>9-10$ tahun sebanyak 26 orang $(15,30 \%)$, umur >10-11 tahun dan >11-12 tahun masing-masing sebanyak 30 orang $(17,65 \%)$ dan umur $>12-13$ tahun sebanyak 27 orang 15,88\%. Berdasarkan jenis kelamin, sebagian besar anak adalah perempuan yaitu sebanyak 86 orang $(50,58 \%)$.
Tabel 2: Distribusi Frekuensi Perilaku Makan

\begin{tabular}{clcc}
\hline No & \multicolumn{1}{c}{ Perilaku Makan } & F & \% \\
\hline 1 & $\begin{array}{l}\text { Satiety Responsiveness } \\
\text { (SR); }\end{array}$ & 26 & 15,30 \\
2 & $\begin{array}{l}\text { Slowness in Eating } \\
\text { (SE); }\end{array}$ & 22 & 12,95 \\
3 & $\begin{array}{l}\text { Emotional Under Eating } \\
\text { (EUE); }\end{array}$ & 13 & 7,65 \\
4 & $\begin{array}{l}\text { Food Fussiness (FF); } \\
5\end{array}$ & 30 & 17,65 \\
& $\begin{array}{l}\text { Food Responsiveness } \\
\text { (FR); }\end{array}$ & 22 & 12,95 \\
6 & $\begin{array}{l}\text { Emotional Over-Eating } \\
\text { (EOE); }\end{array}$ & 13 & 7,65 \\
7 & $\begin{array}{l}\text { Enjoyment of Food } \\
\text { (EOF); }\end{array}$ & 16 & 9,40 \\
8 & Desire to Drink (DD); & 28 & 16,46 \\
\hline & $\quad$ Total & $\mathbf{1 7 0}$ & $\mathbf{1 0 0}$ \\
\hline
\end{tabular}

Berdasarkan tabel 2, didapatkan hasil bahwa mayoritas perilaku makan pada anak adalah Food Fussiness (anak yang suka memilih-milih makanan) yaitu sebanyak 17,64\%, diikuti dengan Desire to Drink (anak lebih memilih minuman) sebanyak 16,46\%, kemudian Satiety Responsiveness (anak mudah kenyang) sebanyak $15,30 \%$, selanjutnya masingmasing sebanyak $12,95 \%$ yaitu perilaku makan Slowness in Eating (anak yang lambat makan) dan Food Responsiveness (anak mudah mereespon makanan), kemudian sebanyak 9,40\% termasuk dalam perilaku Enjoyment of Food (anak dapat menikmati makanan) serta Emotional Under Eating (keinginan makan anak yang kurang) dan Emotional Over-Eating 
(keinginan makan anak yang berlebihan) masing-masing sebanyak $7,65 \%$.

Perilaku makan adalah suatu istilah untuk menggambarkan perilaku yang berhubungan dengan tata krama makan, frekuensi makan, pola makan, kesukaan makan dan pemilihan makanan. Perilaku makan anak adalah suatu tingkah laku, yang dapat dilihat dan diamati, yang dilakukan oleh anak dalam rangka memenuhi kebutuhan makan yang merupakan kebutuhan dasar yang bersifat fisiologis, merupakan reaksi terhadap stimulus yang berasal dari dalam dirinya dan juga dari luar dirinya. Perilaku makan merupakan respon seseorang terhadap makanan sebagai kebutuhan vital bagi kehidupan. ${ }^{7,8}$

Berdasarkan beberapa hasil penelitian, bahwa ada sekitar $60 \%$ anak Indonesia tidak sarapan pagi sebelum berangkat ke sekolah dan itu menjadi perhatian penuh, sebab sarapan pagi akan memberikan kontribusi penting akan beberapa zat gizi yang diperlukan tubuh seperti protein, lemak, vitamin dan mineral. ${ }^{7,8}$

Selain kebiasaan tidak sarapan pagi, saat ini anak lebih menyukai mengonsumsi makanan jajanan siap saji (fast food). Dari hasil Survei Sosial Ekonomi Nasional (Susenas) yang dilakukan oleh Badan
Pusat Statistik (BPS), menunjukkan bahwa persentase pengeluaran rata-rata per kapita penduduk untuk makanan jajanan (termasuk fast food) meningkat dari 9,13\% menjadi $11,37 \%{ }^{8,9}$

Tabel 3: Distribusi Frekuensi Status Gizi

\begin{tabular}{clcc}
\hline No & Status Gizi & F & \% \\
\hline 1 & Gizi Kurang & 0 & 0 \\
2 & Kurus & 51 & 30,00 \\
3 & Normal & 58 & 34,12 \\
4 & Gizi Lebih & 43 & 25,30 \\
5 & Obesitas & 18 & 10,58 \\
\hline \multicolumn{2}{r}{ Total } & 170 & 100 \\
\hline
\end{tabular}

Berdasarkan Tabel 3, diketahui bahwa sebanyak $34,12 \%$ anak termasuk dalam kategori gizi normal, sebanyak $30,00 \%$ anak termasuk kategori kurus, sebanyak 25,30\% anak termasuk kategori gizi lebih, sebanyak 10,60\% anak obesitas dan tidak ada anak dalam kategori gizi kurang.

Status gizi adalah keadaan tubuh sebagai akibat konsumsi makanan dan penggunaan zat-zat gizi, dibedakan antara gizi kurang, baik dan lebih. Status gizi merupakan ekspresi dari keadaan keseimbangan dalam bentuk variabel tertentu atau perwujudan dari nutrisi dalam bentuk variabel tertentu. ${ }^{10}$

Faktor-faktor yang berpengaruh terhadap status gizi terbagi menjadi dua yaitu meliputi faktor internal dan faktor 
eksternal. Faktor internal merupakan faktor yang ada dalam diri anak itu sendiri, yang meliputi status gizi kesehatan, umur, jenis kelamin, dan ukuran tubuh. Status kesehatan berkaitan dengan adanya hambatan reaksi imunologis dan berhubungan dengan terjadinya prevalensi dan beratnya penyakit infeksi, seperti kwarshiokor atau marasmus sering didapatkan pada taraf yang sangat berat. Infeksi sendiri mengakibatkan penderita kehilangan bahan makanan melalui muntah-muntah dan diare. Faktor umur sangat penting dalam penentuan status gizi. Kesalahan penentuan umur akan menyebabkan interpretasi status gizi menjadi salah. Hasil pengukuran tinggi badan dan berat badan yang akurat, menjadi tidak berarti bila tidak disertai dengan penentuan umur yang tepat. Faktor eksternal yang dapat mempengaruhi status gizi yaitu faktor yang datang atau ada dari luar anak itu sendiri, yang meliputi pengetahuan ibu dan faktor ekonomi. ${ }^{11,12}$

Tabel 4 Hubungan Perilaku Makan dan Status Gizi Pada Anak Usia Sekolah Dasar

\begin{tabular}{|c|c|c|c|c|c|c|c|c|c|c|c|c|c|}
\hline \multirow{3}{*}{ No } & \multirow{3}{*}{$\begin{array}{l}\text { Perilaku } \\
\text { Makan }\end{array}$} & \multicolumn{10}{|c|}{ Status Gizi } & \multirow{3}{*}{ Total } & \multirow{3}{*}{$\begin{array}{c}p \\
\text { value }\end{array}$} \\
\hline & & \multicolumn{2}{|c|}{ Kurang } & \multicolumn{2}{|c|}{ Kurus } & \multicolumn{2}{|c|}{ Normal } & \multicolumn{2}{|c|}{ Lebih } & \multicolumn{2}{|c|}{ Obesitas } & & \\
\hline & & $\mathbf{F}$ & $\%$ & $\mathbf{F}$ & $\%$ & $\mathbf{F}$ & $\%$ & $\mathbf{F}$ & $\%$ & $\mathbf{F}$ & $\%$ & & \\
\hline 1 & $\begin{array}{l}\text { Satiety } \\
\text { Responsiveness }\end{array}$ & & & 17 & 33,33 & 9 & 17,24 & & & & & 26 & \\
\hline 2 & $\begin{array}{l}\text { Slowness in } \\
\text { Eating }\end{array}$ & & & 12 & 23,53 & 10 & 17,24 & & & & & 22 & \\
\hline 3 & $\begin{array}{l}\text { Emotional } \\
\text { Under Eating }\end{array}$ & & & 9 & 17,65 & 4 & 6,90 & & & & & 13 & \\
\hline 4 & Food Fussiness & & & 2 & 3,92 & 8 & 12,07 & 13 & 30,23 & 7 & 38,90 & 30 & 0,001 \\
\hline 5 & $\begin{array}{l}\text { Food } \\
\text { Responsiveness }\end{array}$ & & & & & 15 & 25,86 & 7 & 16,28 & & & 22 & \\
\hline 6 & $\begin{array}{l}\text { Emotional } \\
\text { Over-Eating }\end{array}$ & & & & & & & 7 & 16,28 & 6 & 33,33 & 13 & \\
\hline 7 & $\begin{array}{l}\text { Enjoyment of } \\
\text { Food }\end{array}$ & & & & & 9 & 15,52 & 7 & 16,28 & & & 16 & \\
\hline 8 & Desire to Drink & & & 11 & 21,57 & 3 & 5,17 & 9 & 20,93 & 5 & 27,77 & 28 & \\
\hline & Total & 0 & $\mathbf{0}$ & 51 & 100 & 58 & 100 & 43 & 100 & 18 & 100 & 170 & \\
\hline
\end{tabular}

Berdasarkan Tabel 4, diketahui bahwa anak yang memiliki status gizi kurus sebagian besar $(33,33 \%)$ memiliki Jurnal Penelitian Kesehatan STIKes Dharma Husada Bandung perilaku makan Satiety Responsiveness (anak mudah kenyang), anak yang memiliki status gizi normal sebagian 
JURNAL SEHAT MASADA VOLUME XIV NOMOR 1 Januari 2020 ISSN : 1979-2344

besar $(25,86 \%)$ memiliki perilaku makan Food Responsiveness (anak mudah mereespon makanan), anak yang memiliki status gizi lebih sebagian besar $(30,23 \%)$ memiliki perilaku makan Food Fussiness (anak memilih-milih makanan), begitu juga anak yang memiliki status gizi obesitas sebagian besar $(38,90 \%)$ memiliki perilaku makan Food Fussiness (anak memilihmilih makanan).

Pada anak usia sekolah dasar kelas bawah (umur 7-10 tahun), anak sudah dapat menentukan makanan yang disukai karena mereka sudah mengenal lingkungan. Untuk itu, pengawasan dari orang tua sangat diperlukan agar anak tidak salah memilih makanan karena pengaruh lingkungan. Anak usia sekolah dasar masih dalam tahap pertumbuhan sehingga kebutuhan gizinya harus tetap seimbang. Sedangkan pada anak usia sekolah dasar (umur >10-13 tahun) tahun sudah harus dibagi dalam jenis kelaminnya mengingat kebutuhan mereka yang berbeda. Anak laki-laki lebih banyak melakukan aktivitas fisik sehingga mmerlukan kalori yang lebih banyak dibandingkan anak perempuan, pada usia ini biasanya anak perempuan sudah mengalami masa haid sehingga memerlukan lebih banyak protein, zat besi dari usia sebelumnya. ${ }^{13,14}$

Anak dengan kategori gizi kurus sebagian besar memiliki perilaku makan Satiety Responsiveness (anak mudah kenyang) hal ini dapat terlihat dari hasil kuesioner yang menunjukkan bahwa anak tidak memiliki selera makan yang besar, anak sering meninggalkan makanan di piringnya setelah makan, anak sering kenyang sebelum menyelesaikan makanan, anak mudah kenyang, anak tidak bisa makan makanan jika sudah makan cemilan.

Pada anak usia sekolah dasar banyak makanan yang dijual dipinggir jalan atau tempat umum dekat sekolah yang hanya mengandung karbohidrat dan garam saja sehingga akan membuat membuat anak cepat kenyang namun dapat mengganggu nafsu makan anak jika dibiarkan berlarut-larut sehingga akan mengganggu atau menghambat pertumbuhan tubuhnya.

Anak dengan kategori gizi lebih dan obesitas mayoritas memiliki perilaku makan Food Fussiness (anak memilih-milih makanan), hal ini terlihat dari hasil kuesioner yang menunjukkan bahwa anak sering menolak makanan baru dan tidak menikmati saat mencoba makanan baru, ini mungkin dikarenakan pada usia sekolah dasar, anak-anak 
JURNAL SEHAT MASADA VOLUME XIV NOMOR 1 Januari 2020 ISSN :

1979-2344

cenderung memilih makanan

disajikan dan lebih memilik untuk jajan

berdasarkan warna, rasa dan tekstur, di kantin bersama temannya.

pada usia sekolah ini kecenderungan untuk lebih memilih fast food/junk food atau makanan siap saji sangat diminati anak.

Anak yang menyukai junk food, dan mengkonsumsinya secara berlebihan dapat berpengaruh kurang baik bagi kesehatan karena asupan gizi yang diperoleh tidak seimbang, dan juga memicu terjadinya obesitas/kegemukan. Fastfood/junkfood mengandung kalori, protein, lemak dan sodium yang tinggi, sementara kandungan vitamin A, C, E, kalsium, zat besi, asam folat serta serat relatif rendah. Seorang anak yang memilih menu 1 porsi paha goreng (330 kal), kentang goreng (330 kal) dan satu gelas minuman ringan (150 kal) akan mendapatkan 810 kalori; sedangkan kebutuhan energi 1750 kalori, pada satu kali makan anak telah memenuhi 1/2 kebutuhan kalori dalam sehari. ${ }^{9,15}$

Perilaku makan Food Fussiness (anak memilih-milih makanan) juga dapat dipengaruhi teman sebaya atau lingkungan. Misalnya saat jam istirahat anak terkadang tidak mau memakan bekal yang dibawa atau saat kegiatan makan sehat ada beberapa anak yang menolak untuk makan menu yang

4. Gigante, D. P., Maciel, F. V., \& Matijasevich, A. (2015). Children's 
eating behavior: comparison between normal and overweight children from a school in Pelotas,. Elsevier, 33(1), 42-49. https://doi.org/http://dx.doi.org/10.1 016/j.rpped.2014.11.007

5. Demir, D., \& Bektas, M. (2017). Eating Behaviors The effect of childrens eating behaviors and parental feeding style on childhood obesity. Eating Behaviors, 26, 137142.

https://doi.org/10.1016/j.eatbeh.201 7.03.004

6. Aziza, Y. D. A. (2013). Hubungan antara Perilaku Makan Anak dengan Perilaku Orang Tua dalam Pemberian Makan pada Toddler di Sleman Yogyakarta

7. Association of children' $s$ eating behaviors with parental education , and teachers ' health awareness, attitudes and behaviors: a national school-based survey in China. European Journal of Public Health, 24(6), $\quad$ 880-887. https://doi.org/10.1093/eurpub/ckt1 77

8. Herawati, H. D., Gamayanti, I. L., Fahmy, A., Tsani, A., Made, I., \& Gunawan, A. (2016). Perilaku makan berlebih dan hubungannya dengan kegemukan pada anak prasekolah Excessive eating behavior and corellation with overweight in preschool children. Gizi Dan Dietetik Indonesia, 4(1), 161-169. https://doi.org/10.21927/ijnd.2016. 4(3).161-169

9. Iklima, N. (2017). Gambaran Pemilihan Makanan Jajanan Pada Anak Usia Sekolah Dasar. Jurnal Keperawatan BSI, 5(1), 8-17.

10. Centers for Disease Control and Prevention. (2015). Measuring Children's Height and Weight Accurately At Home. Retrieved from

https://www.cdc.gov/healthyweight /assessing/bmi/childrens_bmi/meas uring_chi ldren.html

11. Elisa Pahlevi, A. (2012). Determinan Status Gizi Pada Siswa Sekolah Dasar. Jurnal Kesehatan Masyarakat, 7(2), 122-126. https://doi.org/http://dx.doi.org/10.1 5294/kemas.v7i2.2807

12. Indriyani, R. A. (2015). Hubungan Pola Asuh Makan dengan Status Gizi Usia Anak Sekolah di SDN Teluk Pucung VI Bekasi. Kesejahteraan Keluarga Dan Pendidikan, 5(1), 11-17.

13. Hardinsyah, \& Supariasa, I. . (Ed.). (2016). Ilmu Gizi: Teori dan Aplikasi. Jakarta: EGC.

14. Jahri, I. W. S. Y. E. (2016). Gambaran Status Gizi Pada Siswa. Jom Fk, 3(2), 1-12.

15. Kartini, S. (2013). Faktor Risiko Obesitas pada Anak 5-15 Tahun di Indonesia. ResearchGate, 1-10. https://doi.org/10.1371/journal.pone .003900 